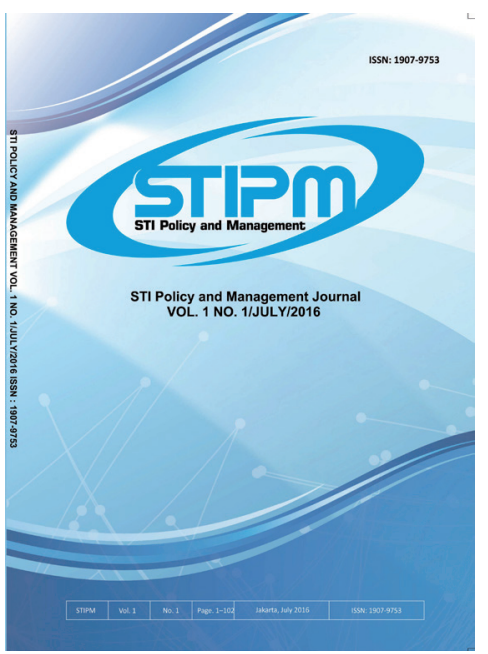

Journal of STI Policy and Management

Publication details, including instructions for authors and subscription information: http://www.stipmjournal.org/

\title{
Intellectual Property Creation of Japanese Companies in China and Thailand
}

\section{Masayuki Kondo}

Graduate School of Environment and Information Sciences

Yokohama National University Japan

Version of record first published: 15 July 2016

To cite this article: Kondo, M. (2016). Intellectual Property Creation of Japanese Companies in China and Thailand. Journal of STI Policy and Management, 1(1), 29-39

To link to this article: http://dx.doi.org/10.14203/stipm.v1i1

ISSN 1907-9753 (Print); ISSN 2502-5996 (online)

Accreditation Number: 622/AU3/P2MI-LIPI/03/2015

Full terms and conditions of use: https://creativecommons.org/licenses/by-nc-sa/4.0/

You are free to:

- Share : copy and redistribute the material in any medium or format

- Adapt : remix, transform, and build upon the material

- The licensor cannot revoke these freedoms as long as you follow the license terms.

Under the following terms:

Attribution - You must give appropriate credit, provide a link to the license, and indicate if changes were made. You may do so in any reasonable manner, but not in any way that suggests the licensor endorses you or your use.

NonCommercial - You may not use the material for commercial purposes.

ShareAlike - If you remix, transform, or build upon the material, you must distribute your contributions under the same license as the original.

No additional restrictions - You may not apply legal terms or technological measures that legally restrict others from doing anything the license permits.

Notices:

- You do not have to comply with the license for elements of the material in the public domain or where your use is permitted by an applicable exception or limitation.

- No warranties are given. The license may not give you all of the permissions necessary for your intended use. For example, other rights such as publicity, privacy, or moral rights may limit how you use the material.

- If you copy the dataset merely to extract the uncopyrightable data elements would not need permission to do so. However, if you republish the full dataset or using the copyrightable data layers require a permission from PAPPIPTEK-LIPI. 


\section{JOURNAL OF STI POLICY AND MANAGEMENT}

Volume 1 No. 1 July 2016

\section{LIST OF CONTENTS}

Innovation System Reform in Indonesia and Vietnam: A new Role for Universities?

Erik Baark.

Technology and Standardization Strategies related to the Diffusion of Smart Houses: The Case of ECHONET in Japan

Kumiko Miyazaki, Kentaro Nishida

Intellectual Property Creation of Japanese Companies in China and Thailand

Masayuki Kondo.

Technological Capability Upgrading and Entrepreneurship: Case Study of Selected Indonesian Fish Processing Companies

Erman Aminullah, Trina Fizzanty, Galuh S. Indraprahasta, and Indri J. Asmara

Influential Factors of Evidence-Based Energy Policy-making: Government Regulation on Targeting Renewable Energy in Indonesia

Wati Hermawati, Prakoso Bhairawa Putera, Dudi Hidayat, and Ishelina Rosaira P.

Finding the Most Efficient Technology Transfer Route Using Dijkstra Algorithm to Foster Innovation: The Case of Essential Oil Developments in the Research Center for Chemistry at the Indonesian Institute of Sciences

Arief A. R. Setiawan, Anny Sulaswatty, and Agus Haryono 


\title{
if STI POLICY AND MANAGEMENT

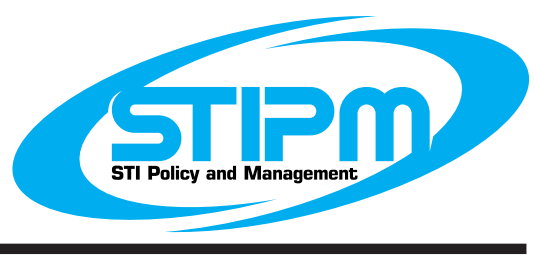

\section{Intellectual Property Creation of Japanese Companies in China and Thailand}

\author{
Masayuki Kondo \\ Graduate School of Environment and Information Sciences \\ Yokohama National University Japan
}

\begin{tabular}{|c|c|}
\hline ARTICLE INFO & ABSTRACT \\
\hline Article History: & \multirow{12}{*}{$\begin{array}{l}\text { In the age of globalization, Japanese companies are globalizing their } \\
\text { operations. They have recently been increasing the number of overseas } \\
\text { R\&D centers in Asia, especially in China and Thailand. Using the } \\
\text { United States patent and industrial design data, the paper finds the } \\
\text { following points quantitatively. Japanese companies are increasing the } \\
\text { number of patents and industrial designs created in the two countries. } \\
\text { They used local talents from the beginning in China for both patents } \\
\text { and industrial designs. In Thailand, they used local talents for industrial } \\
\text { designs from the beginning, while Japanese expertise in Thailand was } \\
\text { used for patents in the beginning. In any case, the role of Japanese in } \\
\text { Japan is important. Compared with multi-national companies (MNCs) } \\
\text { from other countries, the IP creation activities of Japanese companies } \\
\text { are weak compared to their amount of foreign direct investment to } \\
\text { China and Thailand. }\end{array}$} \\
\hline Received : 24 January 2016 & \\
\hline Revised : 12 May 2016 & \\
\hline Accepted : 20 June 2016 & \\
\hline Available online : 15 July 2016 & \\
\hline Keywords: & \\
\hline Intellectual property & \\
\hline Japanese companies & \\
\hline China & \\
\hline Thailand & \\
\hline Overseas R\&D & \\
\hline & \\
\hline
\end{tabular}

C2016 PAPPIPTEK-LIPI All rights reserved

\section{INTRODUCTION: JAPANESE- OWNED R\&D CENTERS IN CHINA AND THAILAND}

In the age of globalization, Japanese companies are globalizing their operations, including in research and development (R\&D). Considering Japan's location in Asia, the number of overseas Japanese R\&D centers in Asia has recently been increasing, especially in China and Thailand (Table 1).

The popularity of China and Thailand as choices for Japanese companies in establishing

\footnotetext{
* Corresponding Author.

E-mail: mkondo@ynu.ac.jp
}

$R \& D$ centers is based on the fact that these two countries are the most popular choices as production sites for Japanese companies (Table 2).

This paper opens with research questions in the next section. Do these R\&D centers operated by Japanese companies in China and Thailand create intellectual properties such as patents and industrial designs? Then, the paper explains the methodology to use the United States patent and industry design database. In Section III, the IP creation of Japanese companies is compared with that of multinational companies (MNCs) of other countries. The paper finds out that the IP creation activities of Japanese companies are weak compared to their amount of foreign direct 
Table 1.

Overseas R\&D Sites of Japanese Companies

\begin{tabular}{llll}
\hline Ranking & $\mathbf{2 0 1 2}$ & $\mathbf{2 0 1 1}$ & $\mathbf{2 0 1 0}$ \\
\hline 1 & China $10.8 \%$ & China $9.8 \%$ & China $8.4 \%$ \\
2 & The United States $6.0 \%$ & The United States $6.4 \%$ & The United States $6.0 \%$ \\
3 & Western Europe 3.7\% & Western Europe $4.7 \%$ & Western Europe $3.9 \%$ \\
4 & Thailand $3.0 \%$ & Thailand $2.5 \%$ & Thailand $2.3 \%$ \\
5 & Korea $2.0 \%$ & Korea $1.6 \%$ & Korea $1.5 \%$ \\
\hline
\end{tabular}

Note. The data means the ratio of companies that possess R\&D sites in a respective country.

Source: JETRO (2012), 2011FY Survey on International Operations of Japanese Firms (in Japanese), March 2012 and JETRO (2013), 2012FY Survey on International Operations of Japanese Firms (in Japanese), March 2013.

Table 2.

Overseas Manufacturing Sites of Japanese Companies

\begin{tabular}{llll}
\hline Ranking & $\mathbf{2 0 1 2}$ & $\mathbf{2 0 1 1}$ & $\mathbf{2 0 1 0}$ \\
\hline 1 & China $43.8 \%$ & China $45.8 \%$ & China $46.2 \%$ \\
2 & Thailand $18.5 \%$ & Thailand $21.8 \%$ & Thailand $24.1 \%$ \\
3 & The United States $2.3 \%$ & The United States $15.9 \%$ & The United States $18.3 \%$ \\
4 & Indonesia $11.0 \%$ & Indonesia $11.9 \%$ & Indonesia $11.9 \%$ \\
5 & Vietnam $10.3 \%$ & Taiwan $10.4 \%$ & Taiwan $11.0 \%$ \\
\hline
\end{tabular}

Note. The data means the ratio of companies that possess manufacturing sites in a respective country.

Source: JETRO (2012), 2011FY Survey on International Operations of Japanese Firms (in Japanese), March 2012 and JETRO (2013), 2012FY Survey on International Operations of Japanese Firms (in Japanese), March 2013.

investment to China and Thailand. In Section IV, this paper analyzes how Japanese companies create intellectual properties (IPs) in China and Thailand, focusing on the utilization of local talents. The paper finds that local talents were employed from the beginning in China for both patents and industrial designs. In Thailand, they used local talents for industrial designs from the beginning, while for patents Japanese expertise in Thailand were used in the beginning. In all cases, the role of Japanese engineers in Japan was found to be important. Finally, the paper states concluding remarks.

\section{RESEARCH QUESTIONS AND METHODOLOGY}

\section{A. Research Questions}

The first research question here is whether Japanese companies create IPs in China and Thailand which are belong to upper-middleincome-conomies. According to the classification of overseas R\&D centers by Ronstadt (1977), the R\&D centers of Japanese companies in China and Thailand are Transfer Technology Units (TTUs) or Indigenous Technology Units (ITUs) because the prevalence of Japanese-owned factories in both China and Thailand imply a close relation to product manufacturing or product improvement.

If they create IPs in China and Thailand,

1. Who are the inventors? Are there local engineers or Japanese engineers in China and Thailand? Are Japanese engineers in Japan also involved?

2. How do the IP creation activities of Japanese companies differ between China and Thailand?

3. How do the IP creation activities of Japanese companies differ between patents and industrial designs?

4. How can the IP creation activities of Japanese companies be compared with those of MNCs from other countries? 
Table 3.

FDI to China in 2012

\begin{tabular}{llrr}
\hline & Country/Region & Amount (million US dollars) & Share(\%) \\
\hline 1 & Hong Kong & 71,289 & 63.8 \\
2 & Japan & 7,380 & 6.6 \\
3 & Singapore & 6,539 & 5.9 \\
4 & Taiwan & 6,183 & 5.5 \\
5 & The United States & 3,130 & 2.8 \\
6 & Korea & 3,066 & 2.7 \\
7 & Germany & 1,471 & 1.3 \\
8 & Netherland & 1,144 & 1.0 \\
9 & The United Kingdom & 1,031 & 0.9 \\
10 & Switzerland & 878 & 0.8 \\
& Others & 9,605 & 8.6 \\
\hline
\end{tabular}

Source: The author tabulated using the data on JETRO HP (October 31, 2013).

In order to answer these questions, the paper adopts a research approach as follows. The paper adopts a fact-finding approach rather than a hypothesis-proving approach or a hypothesisfinding approach since this is a new research area. To clarify the fact of the IP creation activities of Japanese companies, a quantitative approach is employed rather than a qualitative approach. The quantitative approach is explained in the next sub-section.

\section{B. Methodology}

In order to analyze the creation of patents and industrial designs by MNCs in China and Thailand, data are constructed and are analyzed as follows. The United States Patent and Trademark Office (USPTO) Registered Patent Database (1976-2013) was used to retrieve data.

The retrieval conditions for China were:

1. That China must be included as an Inventor Country; and

2. That a specific country must be included as an Assignee Country. In this paper, 'a specific country' is one of the top ten countries measured by foreign direct investment (FDI) amounts to China. ${ }^{1}$

\footnotetext{
Patents could be applied for by local subsidiaries of MNCs. Such analysis was not conducted in this paper, since it is extremely difficult to identify the mother country of a MNC subsidiary by name only. In the case of Thailand, 267 US IPs were applied for by Thai companies and the author identified that a small por-
}

Retrieved data were classified into patents and industrial designs. New plants were excluded. The nationality of each inventor was judged by name as the database has only addresses.

The retrieval conditions for Thailand were similar to those for China.

\section{IP CREATION OF JAPANESE COMPANIES COMPARED WITH MNCS OF OTHER COUNTRIES}

\section{A. In China}

First, we look at the FDI China received. The data detailing FDI to China in 2012 reveals that Hong Kong is an overwhelmingly large investor, occupying 63.8 percent of all FDI to China (Table $3)$. It may be the case that many MNCs established regional headquarter companies in Hong Kong that then invested in China. Hong Kong was followed by Japan, Singapore and Taiwan, whose shares ranged from 5 to 6 percent each.

In order to analyze the creation of patents and industrial designs by MNCs in China, data are constructed and are analyzed as follows. USPTO Registered Patent Database (1976 - 2013) was used to retrieve data as explained in Section II(B.

In China, Taiwanese and US companies were very active and created more than 7,000 patents (Table 4). They were followed by Hong Kong

tion of them were applied for by famous Singaporean subsidiaries, Taiwanese ones and Japanese ones. 
companies (1,231 patents), Japanese ones (701 patents) and German ones (476 patents).

Taiwanese companies created more than ten times as many patents as Japanese companies in China, although they invested an amount similar to Japanese companies in China (Table 5). US companies also created more than ten times as many patents as Japanese companies in China, although they invested half the amount. German companies created 70 percent of patents of Japanese companies in China, although they invested only 20 percent of what Japanese companies did in China. Hong Kong companies, on the other hand, created a little less than two times of patents of Japanese companies in China, although they invested more than ten times of Japanese companies in China.

For industrial designs, Taiwanese companies and US companies were very active in China and created more than 1,000 industrial designs, though their ranking orders differed from the case of patents (Table 4). They were followed by Hong Kong companies, Japanese ones and Dutch ones.

When compared to the FDI amount, Taiwanese and US companies performed much better in the case of industrial designs than the case of patents. US companies created more than 27 times the number of industrial designs of Japanese companies; Taiwanese companies created more than 21 times the number (Table 5). Hong Kong companies created nearly ten times the number of industrial designs of Japanese companies, though they created a little fewer than twice the number patents of Japanese companies in China. For German companies, the situation in the case of industrial designs was the same in the case of patents.

In relation to the all registered patents and industrial designs at USPTO, Japanese companies were not active in creating patents and industrial designs in China. Though the data is only for the year 2012, the ratios of all registered patents and industrial designs at USPTO of MNCs of other countries compared with those of Japanese companies were smaller than the same ratios of patents and industrial designs created in China (Table 5).

\section{B. In Thailand}

The FDI data on Thailand in 2012 shows that Japan is an overwhelmingly large investor, contributing 63.5 percent of all FDI to Thailand (Table 6, Table 7). The position of Hong Kong in the case of China was taken by Japan in the case of Thailand, followed by Singapore, the Netherlands and the United States followed. Their shares were around three percent.

In order to analyze the creation of patents and industrial designs by MNCs in Thailand, data are constructed and are analyzed as follows. USPTO Registered Patent Database (1976 - 2013) was used to retrieve data as in the case of China.

Table 4.

Creation of Patents and Industrial Designs in China by MNCs (1976-2013)

\begin{tabular}{|c|c|c|c|c|}
\hline $\begin{array}{l}\text { Order of } \\
\text { FDI Amount }\end{array}$ & Country/Region & Patents & Industrial Designs & Total \\
\hline 1 & Hong Kong & (3)1231 & (3)576 & 1807 \\
\hline 2 & Japan & (4)701 & $(5) 62$ & 763 \\
\hline 3 & Singapore & 141 & 16 & 157 \\
\hline 4 & Taiwan & (1)7993 & (2)1360 & 9353 \\
\hline 5 & The United States & (2) 7150 & (1)1697 & 8847 \\
\hline 6 & Korea & 181 & 1 & 182 \\
\hline 7 & Germany & (5)476 & 41 & 517 \\
\hline 8 & Netherland & 168 & $(4) 78$ & 246 \\
\hline 9 & The United Kingdom & 58 & 21 & 79 \\
\hline 10 & Switzerland & 321 & 36 & 357 \\
\hline
\end{tabular}

Note. 1. Regarding the data of the United States, multiple counts among States might exist.

2. Numbers in ( ) show the ranking.

Source: The author tabulated using the data on JETRO HP on October 31, 2013. 
Table 5.

IP Creation Indices of Top Five Patent Creating Countries in China

\begin{tabular}{lrrrrr}
\hline & $\begin{array}{l}\text { FDI in China } \\
\text { in 2012 }\end{array}$ & $\begin{array}{l}\text { Patents with } \\
\text { an inventor in } \\
\text { China }\end{array}$ & $\begin{array}{l}\text { Industrial } \\
\text { Designs with } \\
\text { a Designer in } \\
\text { China }\end{array}$ & $\begin{array}{l}\text { Registered } \\
\text { US Patents in } \\
\mathbf{2 0 1 2}\end{array}$ & $\begin{array}{l}\text { Registered } \\
\text { US Industrial } \\
\text { Designs in 2012 }\end{array}$ \\
\hline Japan & 1.0 & 1.0 & 1.0 & 1.0 & 1.0 \\
Taiwan & 1.1 & 11.4 & 21.9 & 0.2 & 0.5 \\
The United States & 0.5 & 10.2 & 27.4 & 2.4 & 6.6 \\
Hong Kong & 10.9 & 1.8 & 9.3 & 0.01 & 0.1 \\
Germany & 0.2 & 0.7 & 0.7 & 0.3 & 0.6 \\
\hline
\end{tabular}

Source: The author.

Table 6.

FDI to Thailand in 2012 (the order of FDI amount)

\begin{tabular}{llrrr}
\hline & Country/Region & \# of investments & Amount (million Baht) & Share(\%) \\
\hline 1 & Japan & 761 & 348,430 & 63.5 \\
2 & Singapore & 103 & 19,418 & 3.5 \\
3 & Netherland & 36 & 17,971 & 3.3 \\
4 & The United States & 49 & 17,890 & 3.3 \\
5 & Hong Kong & 33 & 12,864 & 2.3 \\
6 & Australia & 27 & 12,452 & 2.3 \\
7 & Taiwan & 58 & 11,711 & 2.1 \\
8 & China & 38 & 7,901 & 1.4 \\
9 & Malaysia & 37 & 7,739 & 1.4 \\
10 & Switzerland & 16 & 6,152 & 1.1 \\
10 & India & 25 & 6,100 & 1.1 \\
\hline
\end{tabular}

Source: The author tabulated using the data on JETRO HP (October 31, 2013).

Table 7.

FDI to Thailand in 2012 (the order of the number of FDI)

\begin{tabular}{llrrr}
\hline & Country/Region & \# of investments & Amount (million Baht) & Share (\%) \\
\hline 1 & Japan & 761 & 348,430 & 63.5 \\
2 & Singapore & 103 & 19,418 & 3.5 \\
3 & Taiwan & 58 & 11,711 & 2.1 \\
4 & The United States & 49 & 17,890 & 3.3 \\
5 & Korea & 48 & 3,988 & 0.7 \\
6 & China & 38 & 7,901 & 1.4 \\
7 & Malaysia & 37 & 7,739 & 1.4 \\
8 & Netherland & 36 & 17,971 & 3.3 \\
9 & Germany & 34 & 2,942 & 0.5 \\
10 & Hong Kong & 33 & 12,864 & 2.3 \\
\hline
\end{tabular}

Source: The author tabulated using the data on JETRO HP (October 31, 2013).

Retrieval conditions were similar to those in the case of China. The difference was that the top ten countries were retrieved using FDI amount or FDI by project numbers.

In Thailand, US companies were very active and created nearly 400 patents (Table 8 ). The rank is followed by Japanese companies ( 84 patents),
German ones (32 patents), Taiwanese ones (22 patents) and Dutch ones (16 patents).

US companies created more than four times as many patents as Japanese companies in Thailand, although they invested only five percent the amount (Table 9). German, Taiwanese and Dutch companies each created 20 to 40 percent of the 
patents created by Japanese companies, though their investment amount is less than five percent of Japanese companies.

For industrial designs, US companies were also in the lead with 41 industrial designs (Table 8). They were followed by Japanese companies, as was the case in patents, with 19 industrial designs. The ratio of industrial designs created by US companies compared with Japanese companies was 2.2. This ratio was much smaller that the US-Japan ratio in the case of patents.

The countries taking the third and fourth places differed from the case of patents. The third was Swiss companies (12 industrial designs); and the fourth was Hong Kong companies (10 industrial designs). The fifth was Taiwanese companies (2 industrial designs).
Based on their respective FDI amounts, German, Taiwanese and Dutch companies created industrial designs less actively when compared to Japanese companies (Table 9). However, US companies created industrial designs more actively than Japanese companies, based on their FDI amount.

When considering all registered patents and industrial designs at USPTO, Japanese companies were not very active in creating patents in Thailand. Though the data is only for the year 2012, the ratios of all registered patents at USPTO of MNCs of other countries compared with those of Japanese companies were smaller than the same ratios of patents created in Thailand (Table 9). For industrial designs, the situation was the opposite, though the number of industrial designs was small.

Table 8.

Creation of Patents and Industrial Designs in Thailand by MNCs (1976-2013)

\begin{tabular}{|c|c|c|c|c|}
\hline $\begin{array}{l}\text { Order of the } \\
\text { number of FDI }\end{array}$ & Country/Region & Patents & Industrial Designs & Total \\
\hline 1 & Japan & (2) 84 & (2) 19 & 103 \\
\hline 2 & Singapore & 3 & 0 & 3 \\
\hline 3 & Taiwan & (4) 22 & (5) 2 & 24 \\
\hline 4 & The United States & (1) 369 & (1) 41 & 410 \\
\hline 5 & Korea & 4 & 0 & 4 \\
\hline 6 & China & 2 & 1 & 3 \\
\hline 7 & Malaysia & 0 & 0 & 0 \\
\hline 8 & Netherland & (5) 16 & 0 & 16 \\
\hline 9 & Germany & (3) 32 & 0 & 32 \\
\hline 10 & Hong Kong & 9 & (4) 10 & 19 \\
\hline Within Top 10 & Australia & 9 & 0 & 9 \\
\hline regarding FDI & Switzerland & 9 & (3) 12 & 21 \\
\hline Amount & India & 1 & 0 & 1 \\
\hline
\end{tabular}

Notes. 1. The data period is 1976-August 2013 for the United States.

2. Numbers in ( ) show the ranking.

Source: The author tabulated using the data on JETRO HP (October 31, 2013).

Table 9.

IP Creation Indices of Top Five Patent Creating Countries in Thailand

\begin{tabular}{llllll} 
& $\begin{array}{l}\text { FDI in } \\
\text { Thailand in } \\
\mathbf{2 0 1 2}\end{array}$ & $\begin{array}{l}\text { Patents with } \\
\text { an inventor in } \\
\text { Thailand }\end{array}$ & $\begin{array}{l}\text { Industrial } \\
\text { Designs with } \\
\text { a Designer in } \\
\text { Thailand }\end{array}$ & $\begin{array}{l}\text { Registered } \\
\text { US Patents in } \\
\mathbf{2 0 1 2}\end{array}$ & $\begin{array}{l}\text { Registered } \\
\text { US Industrial } \\
\text { Designs in 2012 }\end{array}$ \\
\hline Japan & $\mathbf{1 . 0 0}$ & $\mathbf{1 . 0}$ & $\mathbf{1 . 0}$ & $\mathbf{1 . 0}$ & $\mathbf{1 . 0}$ \\
The United States & 0.05 & 4.4 & 2.2 & 2.4 & 6.6 \\
Germany & 0.01 & 0.4 & 0.0 & 0.3 & 0.5 \\
Taiwan & 0.03 & 0.3 & 0.1 & 0.2 & 0.5 \\
Netherland & 0.05 & 0.2 & 0.0 & 0.04 & 0.1 \\
\hline
\end{tabular}

Source: The author. 
In comparison, the performance of Japanese companies was different in China. In China, Japanese companies were relatively good in creating patents relative to the MNCs of other countries - better than in creating industrial designs, while they were relatively good in creating industrial designs relative to the MNCs of other countries than in creating patents in Thailand (Table 5 and 9).

\section{ROLE OF LOCAL ENGINEERS, THAT OF LOCAL JAPANESE ENGINEERS AND THAT OF JAPANESE ENGINEERS IN JAPAN}

\section{A. In China}

For patents, Japanese companies started creating patents in China in the 1980s. They increased the number of patents created in China gradually and made a rapid increase in the 2000 s.

The roles of Chinese and Japanese engineers in China as well as Japanese engineers in Japan were as follows. Chinese engineers were main inventors from the 1980s and Japanese engineers in China became more involved as time passed by (Table 10 and Figure 1). Cases where no Chinese engineers were involved increased though the absolute number was small. Japanese engineers in Japan were involved in any cases to a large extent. As Subramaniam and Venkatraman (2001) suggest, cross-national teams have great new product development capability. The presence of Japanese engineers in Japan was apparent in the cases where no Chinese were involved. As a whole the involvement of Japanese engineers in Japan was decreasing.

For industrial designs, Japanese companies started creating industrial designs in China recently in the 2000s. They increased the number of industrial designs created in China gradually.

The roles of Chinese designers, Japanese designers in China and Japanese designers in Japan were as follows (Table 11 and Figure 1). Japanese companies started creating industrial designs mainly by Chinese designers and to some extent by Japanese designers in China. The involvement of Japanese designers in Japan was a little more than half in the cases where Chinese designers were involved and was heavy in the cases where Chinese designers were not involved and Japanese designers in China were involved.

\section{B. In Thailand}

For patents, the creation activities of Japanese companies in Thailand started in the late 1980s. The number of patents created in Thailand

Table 10.

The Changes of the Roles of Chinese Engineers in Patent Creation (unit: \%)

\begin{tabular}{|c|c|c|c|c|}
\hline \multirow[b]{2}{*}{ Decade } & \multirow[b]{2}{*}{$\begin{array}{l}\text { With Chinese inventors } \\
\text { (of which with Japanese } \\
\text { inventors in Japan) } \\
\text { <of which with Japanese } \\
\text { inventors in China> }\end{array}$} & \multicolumn{2}{|c|}{ With no Chinese inventors } & \multirow[b]{2}{*}{$\begin{array}{l}\text { Total (of which with } \\
\text { Japanese inventors } \\
\text { in Japan) }\end{array}$} \\
\hline & & $\begin{array}{l}\text { With Japanese } \\
\text { inventors in Japan } \\
\text { (of which with } \\
\text { Japanese inventors } \\
\text { in Japan) }\end{array}$ & $\begin{array}{l}\text { With no Japanese } \\
\text { inventors in Japan } \\
\text { (of which with } \\
\text { Japanese inventors } \\
\text { in Japan) }\end{array}$ & \\
\hline $1980 \mathrm{~s}$ & $100(56)$ & & & $\begin{array}{c}100(56) \\
9 \text { patents }\end{array}$ \\
\hline $1990 \mathrm{~s}$ & $93(69)<2>$ & $7(100)$ & & $\begin{array}{c}100(71) \\
45 \text { patents }\end{array}$ \\
\hline $2000 \mathrm{~s}$ & $80(45)<6>$ & $19(90)$ & $1(71)$ & $\begin{array}{c}100(54) \\
471 \text { patents }\end{array}$ \\
\hline $2010 \mathrm{~s}$ & $79(37)<21>$ & $21(100)$ & & $\begin{array}{c}100(33) \\
24 \text { patents }\end{array}$ \\
\hline
\end{tabular}

Note. The number of data in the 1980s (1984-1989) and the number of data in the 2010s (2010-2011) are limited. Source: The author. 
Table 11.

The Changes of the Roles of Chinese Designers in Industrial Design Creation (unit: \%)

\begin{tabular}{|c|c|c|c|c|}
\hline \multirow[b]{2}{*}{ Decade } & \multirow[b]{2}{*}{$\begin{array}{l}\text { With Chinese inventors } \\
\text { (of which with Japanese } \\
\text { inventors in Japan ) } \\
\text { <of which with Japanese } \\
\text { inventors in China> }\end{array}$} & \multicolumn{2}{|c|}{ With no Chinese inventors } & \multirow{2}{*}{$\begin{array}{l}\text { Total } \\
\text { (of which } \\
\text { with Japanese } \\
\text { inventors in } \\
\text { Japan ) }\end{array}$} \\
\hline & & $\begin{array}{l}\text { With Japanese } \\
\text { inventors in Japan } \\
\text { (of which } \\
\text { with Japanese } \\
\text { inventors in } \\
\text { Japan) }\end{array}$ & $\begin{array}{l}\text { With no Japanese } \\
\text { inventors in Japan } \\
\text { (of which with } \\
\text { Japanese inventors } \\
\text { in Japan) }\end{array}$ & \\
\hline $1980 \mathrm{~s}$ & - & - & - & - \\
\hline $1990 \mathrm{~s}$ & - & - & - & - \\
\hline $2000 \mathrm{~s}$ & $88(54)<4>$ & $6(100)$ & $6(50)$ & $\begin{array}{l}100(56) \\
\mathbf{3 2} \text { designs }\end{array}$ \\
\hline $2010 \mathrm{~s}$ & $100(95)$ & & & $\begin{array}{l}100(95) \\
20 \text { designs }\end{array}$ \\
\hline
\end{tabular}

Note. Both the number of data in the 2000s (2003-2009) and the number of data in the 2010s (2010-2012) are limited. Source: The author.

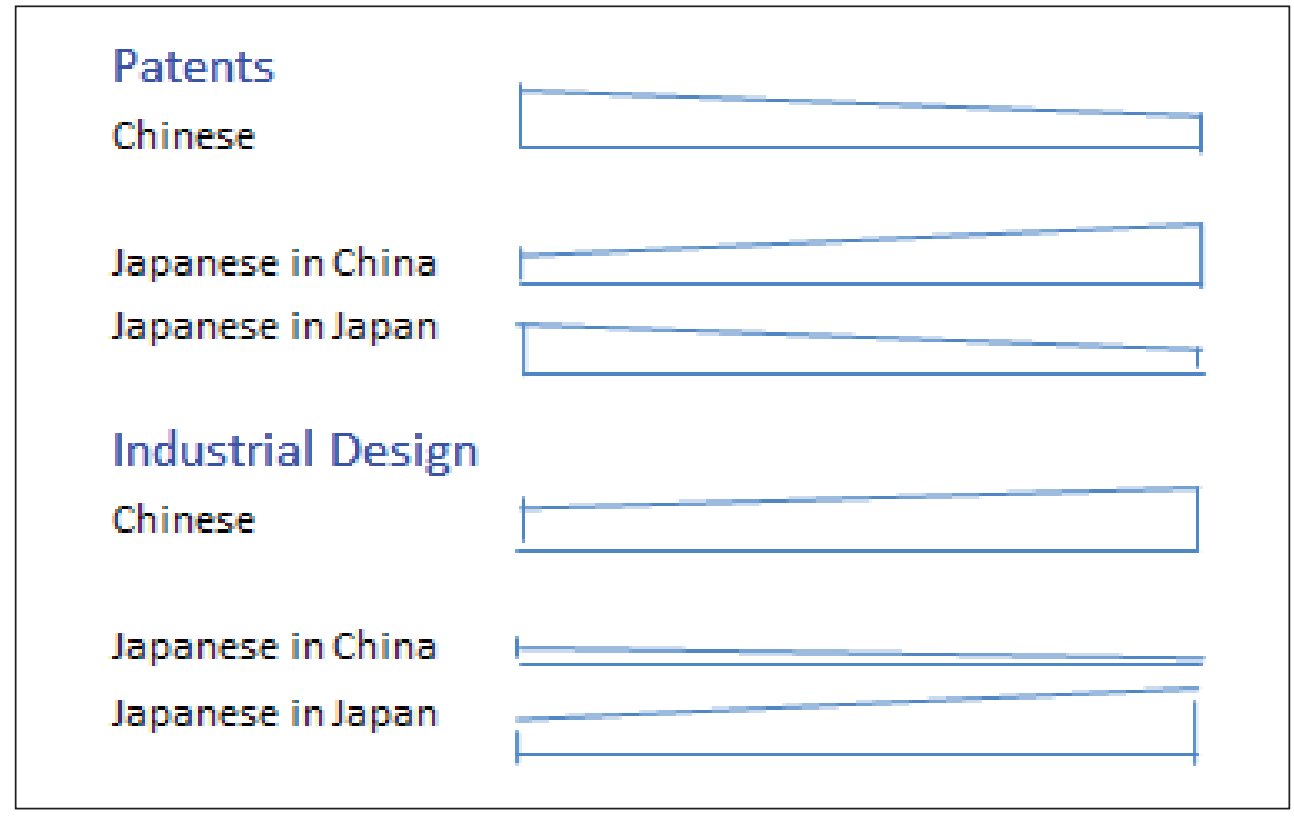

Figure 1. The Changes of the Roles of Chinese Designers in Industrial Design Creation (unit: \%)

gradually increased, making a rapid increase in the 2000s.

The roles of Thai and Japanese designers in Thailand as well as Japanese designers in Japan in this case differed from the case in China. In the beginning, patents were created by Japanese engineers in Thailand together with Japanese engineers in Japan (Table 12 and Figure 2). In the 1990s Thai inventors started to appear. Additionally, some foreigners in Thailand were sole inventors. In the 2000s, the role of Thai engineers became substantial in patent creation, though the role of Japanese engineers in Thailand were still important. In all previous decades, Japanese engineers in Japan were closely involved, though their role has slightly diminished recently. An interesting factor is the involvement of inventors in other countries in patent creation. In other words, some patents were created through an international network.

The situation was quite different in the case of industrial designs. The industrial design activities of Japanese companies in Thailand started only in the latter half of the 2000s. The design 
Table 12.

The Changes of the Roles of Thai Engineers in Patent Creation (unit: \%)

\begin{tabular}{|c|c|c|c|c|}
\hline \multirow[b]{2}{*}{ Decade } & \multirow[b]{2}{*}{$\begin{array}{l}\text { With Thai inventors } \\
\text { (of which with } \\
\text { Japanese inventors in } \\
\text { Japan) } \\
\text { <of which with } \\
\text { Japanese inventors in } \\
\text { Thailand> }\end{array}$} & \multicolumn{2}{|l|}{ With no Thai inventors } & \multirow{2}{*}{$\begin{array}{l}\text { Total } \\
\text { (of which with } \\
\text { Japanese inventors } \\
\text { in Japan) }\end{array}$} \\
\hline & & $\begin{array}{l}\text { With Japanese } \\
\text { inventors in Japan } \\
\text { (of which with } \\
\text { Japanese inventors in } \\
\text { Japan) }\end{array}$ & $\begin{array}{l}\text { With no Japanese } \\
\text { inventors in Japan } \\
\text { (of which with } \\
\text { Japanese inventors in } \\
\text { Japan) }\end{array}$ & \\
\hline $1980 \mathrm{~s}$ & & $100(100)$ & & $\begin{array}{l}100(100) \\
2 \text { patents }\end{array}$ \\
\hline $1990 \mathrm{~s}$ & $11(100)<0>$ & $47(78)$ & $42(0)$ & $\begin{array}{l}100(53) \\
19 \text { patents }\end{array}$ \\
\hline $2000 \mathrm{~s}$ & $52(69)<14>$ & $46(54)$ & $2(100)$ & $\begin{array}{l}100(63) \\
56 \text { patents }\end{array}$ \\
\hline $2010 \mathrm{~s}$ & $33(0)<0>$ & $33(50)$ & $33(0)$ & $\begin{array}{l}100(17) \\
6 \text { patents }\end{array}$ \\
\hline
\end{tabular}

Note. The number of data in the 1980s (1988-1989) and the number of data in the 2010s (2010-2012) are limited. Source: The author.

Table 13.

The Changes of the Roles of Thai Designers in Industrial Design Creation (unit: \%)

\begin{tabular}{|c|c|c|c|c|}
\hline \multirow[b]{2}{*}{ decade } & \multirow[b]{2}{*}{$\begin{array}{l}\text { With Thai inventors (of } \\
\text { which with Japanese } \\
\text { inventors in Japan) } \\
\text { <of which with Japanese } \\
\text { inventors in Thailand> }\end{array}$} & \multicolumn{2}{|c|}{ With no Thai inventors } & \multirow{2}{*}{$\begin{array}{l}\text { total } \\
\text { (of which with } \\
\text { Japanese inventors } \\
\text { in Japan) }\end{array}$} \\
\hline & & $\begin{array}{l}\text { With Japanese } \\
\text { inventors in Japan } \\
\text { (of which with } \\
\text { Japanese inventors } \\
\text { in Japan) }\end{array}$ & $\begin{array}{l}\text { With no Japanese } \\
\text { inventors in Japan } \\
\text { (of which with } \\
\text { Japanese inventors } \\
\text { in Japan) }\end{array}$ & \\
\hline $1980 \mathrm{~s}$ & - & - & - & - \\
\hline $1990 \mathrm{~s}$ & - & - & - & - \\
\hline $2000 \mathrm{~s}$ & $91(100)<0>$ & $9(100)$ & & $\begin{array}{l}100(100) \\
11 \text { designs }\end{array}$ \\
\hline $2010 \mathrm{~s}$ & $88(71)<0>$ & $13(0)$ & & $\begin{array}{l}100(63) \\
8 \text { designs }\end{array}$ \\
\hline
\end{tabular}

Note. Both the number of data in the 2000s (2006 -2009) and the number of data in the 2010s (2010 -2012) are limited. Source: The author.

activities were conducted by Thai designers in Thailand and Japanese in Japan (Table 13 and Figure 2). The international comparison of the involvement of Thai engineers was conducted by checking the names of inventors of the patents created by MNCs from various countries ${ }^{2}$.

For patent creation, US and Taiwanese companies showed a high level of involvement of local talents. More than 70 percent of the patents created by these MNCs involved Thai engineers (Table 14). Dutch companies also involved Thai engineers in more than 60 percent of their patents

2 For the case of China, the analysis is still in progress for non-Japanese companies. created in Thailand. Both Japanese and German companies involved Thai engineers in only 60 percent of their patents created in Thailand.

For industrial design creation, Japanese and Hong Kong companies showed a high involvement of local talents (Table 14). Japanese companies involved Thai designers in nearly 90 percent of their industrial designs created in Thailand. US and Taiwanese companies involved Thai designers in around 50 percent of their industrial designs created in Thailand. 


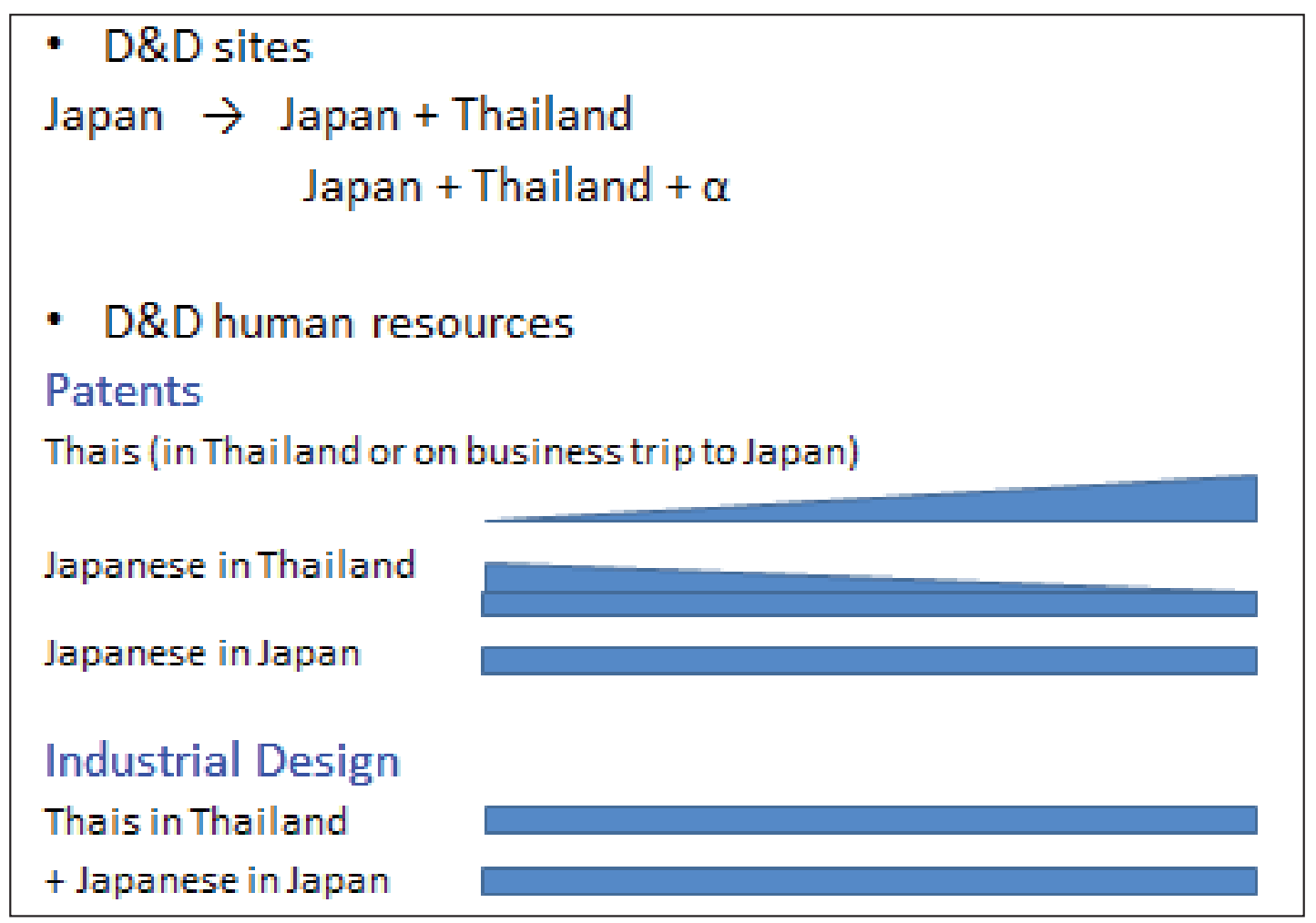

Source: The author.

Figure 2. D\&D (Design and Development Function Transfer

Table 14.

Involvement of Thai Inventors (1976-2013)

\begin{tabular}{crccc}
\hline Country/Region & Patents & $\begin{array}{l}\text { The Ratios of Thai } \\
\text { Engineer Involvement }\end{array}$ & $\begin{array}{l}\text { Industrial } \\
\text { Designs }\end{array}$ & $\begin{array}{l}\text { The Ratios of Thai } \\
\text { Designer Involvement }\end{array}$ \\
\hline The United States & $(1)$ & $72 \%$ & (1) 41 & $46 \%$ \\
Japan & 369 & $38 \%$ & (2) 19 & $89 \%$ \\
Germany & $(2) 84$ & $34 \%$ & 0 & - \\
Taiwan & $(3) 32$ & $75 \%$ & (5) 2 & $50 \%$ \\
Netherland & $(4) 22$ & $63 \%$ & 0 & - \\
Switzerland & $(5) 16$ & $11 \%$ & (3) 12 & $80 \%$ \\
Hong Kong & 9 & $89 \%$ & (4) 10 & $80 \%$ \\
\hline
\end{tabular}

Notes. 1. The data period is 1976-August 2013 for the United States.

2. Four patents from Netherland with Thai inventors are the patents of Hitachi Global Storage Company.

3. Numbers in ( ) show the ranking.

Source: The author.

\section{CONCLUDING REMARKS}

This paper analyzed IP creation activities of Japanese companies in China and Thailand, where they own many overseas factories and overseas $R \& D$ centers.

The paper has found out that Japanese companies create IPs in China and Thailand but their IP creation activities are not so vigorous in comparison to their FDI to China and Thailand. In China, US and Taiwanese MNCs create IPs very vigorously in comparison to their FDI to China. In Thailand, US MNCs and those from other countries create IPs vigorously in comparison to their FDI to Thailand.

The level of local talent mobilization in creating IPs depends on the country. In China, for patents, the level of involving Chinese en- 
gineers was high from the beginning. A small shift occurred from Japanese engineers in Japan to Japanese engineers in China. For industrial designs, the level of involvement of Chinese designers was high from the beginning as well; and the involvement of Japanese designers in Japan increased.

In Thailand, for patents, the level of involvement of Thai engineers was low in the beginning and became greater. The role of Japanese engineers in Japan decreased slightly. For industrial designs, the level of involvement of Thai designers was high from the beginning instead. The importance of the role of Japanese designers in Japan remained unchanged.

The author is interested in Japanese company IP creation activities in other countries such as India and Russia and plans to pursue further details in the case of China and Thailand by more case studies.

\section{ACKNOWLEDGEMENT}

The author is thankful to the funding and supports from Yokohama National University and to the funding of Grants-in-Aid for Scientific Research (C) of the Japan Society for the Promotion of Science.
The author is also thankful to Ms. TIN Youi for checking whether names of inventors were Chinese or not.

\section{REFERENCES}

Kondo, M. (2014). Intellectual property creation of Japanese companies in Thailand. Proceedings of 23rd International Management of Technology (IAMOT) Annual Conference 2014 [CDROM], Washington, D. C., May 22-26, 2014.

Kondo, M. (2015). Intellectual property creation of Japanese companies in China. Proceedings of 6th CAMOT 2015 International Conference, La Rochelle, July 6-8, 2015.

Ronstadt, R. C. (1977). Research and development abroad by U.S. multinationals. New York: Praeger. http://dx.doi.org/10.1002/tie.5060200105

Subramaniam, M., \& Venkatraman, N. (2001). Determinants of transnational new product development capability: testing the influence of transferring and deploying tacit overseas knowledge. Strategic Management Journal, 22, 359-378. http://dx.doi.org/10.1002/smj.163. abs 